\title{
Metabolic Activity of Moulds as a Factor of Building Materials Biodegradation
}

\author{
BEATA GUTAROWSKA* \\ Institute Technology Fermentation and Microbiology, Technical University of Łódź, Poland \\ Received 25 September 2009, revised 6 April 2010, accepted 8 April 2010
}

\begin{abstract}
This paper presents the effect of building materials on the growth and metabolic activity of moulds. In cultures of Aspergillus and Penicillium moulds grown on a model medium with the addition of building materials, the biomass of mycelium, its cellular components - glucan, chitin, ergosterol and the spectrum of enzymes and organic acids produced in the medium were investigated. It was found that on the medium with wallpaper moulds produced more biomass and extracellular enzymes, mainly glycolytic ones. On medium with mortar the growth of mycelium was impeded, production of biomass was $60 \%$ smaller, the quantity of chitin, glucan and ergosterol decreased $13-41 \%$, and the activity of most enzymes was reduced; however the moulds intensively produced organic acids: malic, succinic and oxalic acid. The largest acid production activity was found in medium with addition of mortar; moulds produced the greatest variety of acids and in greater quantities than in the control medium. Metabolic activity of the moulds depends on the type of building material, and may lead to biodeterioration of these materials.
\end{abstract}

Key words: building materials, biodegradation, exoenzymes, moulds, organic acids

\section{Introduction}

In the construction environment, building and finishing materials are colonized by numerous species of mould. The activity of moulds on building materials depends on many factors, including relative humidity, temperature, physical properties of the surface, $\mathrm{pH}$, presence of dust, and light (Korpi et al., 1997; Nielsen et al., 2004). The type of building material has a significant influence on the growth of fungi. Moulds are able to grow on building materials of organic origin containing cellulose, e.g. wood, wallpaper, carton-gypsum board and on inorganic surfaces such as concrete, gypsum, mortar and stone, provided that they find a source of carbon in the form of contaminants - dust or other organic material (Palmer et al., 1991; Pasanen et al., 1997).

An important factor in the development of moulds on building materials is their biodeterioration activity, causing damage of the construction environment (Sand, 1997; Sanchez-Silva and Rosowsky, 2008). Moulds are able to produce many extracellular enzymes, which may damage building materials by using them as a source of nutrients. Another factor of great significance for the biodeterioration of building materials is the production of organic acids by moulds. The formation of organic acids by fungi has been widely documented in stone environments - limestone, sandstone, granite (Petersen et al., 1987; de la Torre et al., 1991; Gomez-Alarcon et al., 1994).

Most studies relating to mould growth in building materials in houses concern the identification of those microorganisms, the conditions for their growth and mycotoxins and organic volatile compounds production and influence on the allergy diseases, mycotoxicosis (Nielsen et al., 1998; Gutarowska et al., 2005; van Lancker et al., 2008). A small number of studies on the subject of growth and metabolites inducing damage to building materials - enzymes, organic acids produced by moulds - provided a basis for the presented investigations.

The feature of the adaptation of moulds in various environments with poor carbon source and low or very high $\mathrm{pH}$ has been described. There is no investigation on the direction of moulds metabolic activity in oligotrophic conditions and unfavourable $\mathrm{pH}$. The aim of the study was to answer the question - what mould metabolic activity factors are responsible for the destruction of building materials of organic and inorganic origin. The scope of the investigation was to

* Corresponding autor: B. Gutarowska, Institute Technology Fermentation and Microbiology, Technical University of Łódź, ul. Wólczańska 171/173, 90-924 Łódź, Poland; phone: (+48) 426313470; fax: (+48) 426365976; e-mail: gustaw@p.lodz.pl 
compare the dry mass of mycelium and the components of mycelium (chitin, glucan, ergosterol) as well as spectrum of extracellular enzymes and organic acids produced during mould growth on media with addition of various building materials compared to the control medium.

\section{Experimental}

\section{Materials and Methods}

Moulds were isolated from the walls in buildings in medium MEA (Malt Extract Agar, Oxoid) with addition of chloramphenicol (0.1\%). After incubation at $27^{\circ} \mathrm{C}$ for 7 days, strains were identified on the Czapek Dox Agar medium (Difco) based on Samson et al., 2000, Flannigan et al., 2001. Four mould species: Aspergillus niger, Aspergillus flavus, Penicillium chrysogenum, Penicillium expansum, the most frequently isolated from buildings, were used in this study.

Media. Moulds were cultured in Mo liquid medium $\left(\mathrm{MgSO}_{4} \times 7 \mathrm{H}_{2} \mathrm{O}, 5 \mathrm{~g} ;\left(\mathrm{NH}_{4}\right)_{2} \mathrm{SO}_{4}, 3 \mathrm{~g} ; \mathrm{KH}_{2} \mathrm{PO}_{4}, 1 \mathrm{~g}\right.$; glucose, $30 \mathrm{~g}$; distilled water, $1 \mathrm{l}$; $\mathrm{pH} 5.8$ ) and in Mo medium with the addition of wallpaper, gypsum board, gypsum and mortar, in three repetitions. An organic component (glucose) was added to medium Mo for initiating growth of moulds and it also simulated organic contaminations of building materials. The building materials came from retail sales outlets. Wallpaper was made from paper, without plastic materials and sticking layer, it was embossed and dyed. Carton-gypsum board was unimpregnated, thickness $9.5 \mathrm{~mm}$, degree of fire resistance A2. Mortar was a dry mixture of cement, quartz fillers and additions of plaster, class CS II in accordance with requirements PN-EN 998-1. Gypsum was GTM class according to PN-B-30042: 1997. Wallpaper and carton from carton-gypsum board were cut to squares $4 \mathrm{~mm}^{2}$, mortar and gypsum were added as powder form, gypsum from carton-gypsum board was ground using mortar to less than $1 \mathrm{~mm}$ size particles. Grinded materials were added in quantity of $7.5 \mathrm{~g}$ to $150 \mathrm{ml}$ of medium in Erlenmeyer flasks and after 1 hour (to stabilization of $\mathrm{pH}$ value) sterilized at $120^{\circ} \mathrm{C}$ for 20 minutes. The media were inoculated with $1 \mathrm{ml}$ of suspension of mould spores (density $1-1.5 \times 10^{6} \mathrm{cfu} / \mathrm{ml}$, was measured using a Thoma chamber). The cultures were grown at $27^{\circ} \mathrm{C}$ for 12 days.

Dry biomass of mycelium was determined after 12 days of incubation of the moulds with three repetitions from separate cultures. The mycelium was separated from the medium by vacuum filtration. The dry mass was determined by a weight-based method, drying at $105^{\circ} \mathrm{C}$ to obtain a constant weight.

Glucan and chitin determination was carried out after 12 days of mould culture growth for three mycelium cell-wall preparations obtained from separate cultures. The method with dodecyl sulphate described by Kisser et al. (1980) was used for preparation of the mycelium cell-wall. A determination of the quantity of glucan in the cell-wall was made (in terms of the content of reducing sugars) using an acid hydrolysis method. Reducing sugars were determined using a DNS method (Rokem et al., 1986). The quantity of chitin in the wall was calculated from the difference between the total reducing sugar content and the quantity of reducing sugars after elimination of glucosamine.

Ergosterol determination was carried out after 12 days of mould incubation, in dry mass of mycelium obtained from three separate cultures. The modified method of Seitz was used for ergosterol determination (Gutarowska and Żakowska, 2002).

Extracellular enzymes in the medium were determined on the first day of the stationary phase of mould growth. A sample of $5 \mathrm{ml}$ of medium after culture was taken and centrifuged at $\mathrm{g}=910$ for $10 \mathrm{~min}$ utes. In the supernatant a determination for the presence of 19 enzymes was made using the API-Zym test (bioMerieux). The determination was made with three repetitions, an enzyme being considered to be present if it occurred in at least two repetitions. The increase in the quantity of enzyme was determined on the basis of the increase in intensity of colouring of the sample in at least two repetitions.

Measurement of $\mathbf{p H}$ was also conducted in the culture of moulds using a Beckman F310 pH meter. The $\mathrm{pH}$ measurement was done three times for each determination.

Organic acids were determined on the first day of the stationary phase of mould growth. A volume of $5 \mathrm{ml}$ liquid culture was taken and centrifuged at $\mathrm{g}=910$ for 10 minutes. The presence of organic acid was determined with the HPLC method in supernatant liquid. The chromatographic analysis was performed with a SpectraSYSTEM P2000 gradient pump (Thermo Separation Products, Riviera Beach Fl., USA) a Rheodyne $7725 \mathrm{i}$ injector valve equipped with a $50 \mu$ l loop (Rheodyne, Cotati, USA) and Spectra SYSTEM RI-150 refractive index detector. The column used was an Aminex HPX 87H, 300×7.8 mm id. (HPLC Organic Acid Analysis Column, Bio-Rad, Hercules CA, USA). The mobile phase was water adjusted to a $\mathrm{pH}$ between 2.1 to 2.15 with sulphuric acid and filtered through a cellulose membrane with $0.45 \mu \mathrm{m}$ micropores (Millipore, Belford, USA). The separation was carried out by isocratic elution with

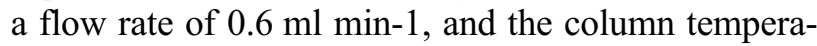
ture was maintained constant at $60^{\circ} \mathrm{C}$. Quantitation was based on the peak area measurement. Water from a Millipore Milli-Q system was used for all solutions, dilution, and the mobile phase. Sulphuric acid 
(95-98 per cent) obtained from J.T. Baker B.V. (Deventer, Holland) was a "Baker instra-analyzed" reagent. Organic acids used as standards were purchased from Supelco (Bellefonte, PA). A mixture of all acids studied was used to optimise peak resolution. The standard of the individual acid was prepared and chromatographed separately in order to determine the retention time for each acid.

Statistical analysis. The values of mycelium components, mycelium dry mass, $\mathrm{pH}$ of medium, acids were subjected to statistical analysis, including determination of the arithmetic mean, standard deviation. The comparative analysis was made between the feature as obtained on the control medium and on a medium with the addition of building material. For this purpose the t-Student statistical test was used, at a significance level of $\lambda=0.95$. Also the frequency of occurrence of acids was calculated.

\section{Results}

In cultures of all studied moulds in media with building materials of organic and mixed origin (wallpaper, carton-gypsum board) a greater quantity of mycelium biomass (about 23-34\%) was obtained, compared with the control medium Mo (Table I). A statistically significant increase in the mycelium biomass was found only in medium Mo with the addition of wallpaper for three strains of the moulds $A$. niger, A. flavus, P. expansum. A small increase of dry mass of mycelium in the medium with carton-gypsum board was observed; statistical analysis did not show any difference between dry mass of mycelium in control medium and medium with carton-gypsum board. In media with the addition of inorganic materials (gypsum, mortar) a smaller mycelium biomass (about $39-60 \%$ ) was obtained, but only in the case of mortar statistical analysis showed a significant difference compared with the control medium. The decrease in mycelium biomass on medium containing mortar was reflected in the decrease in mycelium components - glucan, chitin and ergosterol (Table II). Significant statistical differences between the control medium and medium with mortar were shown. The quantity of glucan decreased in medium with mortar by about 25-37\%; chitin -13-41\%, ergosterol 18-37\%.

The moulds produced a different spectrum of extracellular enzymes depending on the building material on which they grew (Table III). Addition of wallpaper

Table I

Mycelium dry mass of moulds in media with addition of building materials

\begin{tabular}{|c|c|c|c|c|c|c|c|c|c|c|c|c|c|c|}
\hline \multirow{3}{*}{ Moulds } & \multicolumn{14}{|c|}{ Dry mass of mycelium $(\mathrm{g})$ in various media } \\
\hline & \multicolumn{2}{|c|}{ Control Mo } & \multicolumn{3}{|c|}{ Mo + wallpaper } & \multicolumn{3}{|c|}{$\begin{array}{c}\text { Mo }+ \text { carton-gypsum } \\
\text { board }\end{array}$} & \multicolumn{3}{|c|}{ Mo + gypsum } & \multicolumn{3}{|c|}{ Mo + mortar } \\
\hline & $\mathrm{x}$ & $\mathrm{s}$ & $\mathrm{x}$ & $\mathrm{s}$ & test $\mathrm{t}^{*}$ & $\mathrm{x}$ & $\mathrm{s}$ & test $t^{*}$ & $\mathrm{x}$ & $\mathrm{s}$ & test $t^{*}$ & $\mathrm{x}$ & $\mathrm{s}$ & test $\mathrm{t}^{*}$ \\
\hline Aspergillus niger & 0.99 & 0.15 & 1.38 & 0.16 & + & 1.13 & 0.13 & - & 0.89 & 0.11 & - & 0.61 & 0.11 & + \\
\hline Aspergillus flavus & 0.92 & 0.12 & 1.20 & 0.18 & + & 0.99 & 0.19 & - & 0.82 & 0.13 & - & 0.48 & 0.08 & + \\
\hline Penicillium chrysogenum & 0.58 & 0.11 & 0.84 & 0.17 & - & 0.67 & 0.14 & - & 0.51 & 0.13 & - & 0.35 & 0.07 & + \\
\hline Penicillium expansum & 0.70 & 0.11 & 1.07 & 0.21 & + & 0.84 & 0.21 & - & 0.68 & 0.14 & - & 0.27 & 0.10 & + \\
\hline
\end{tabular}

Legend: $\mathrm{x}=$ average value, $\mathrm{s}=$ standard deviation, * statistical analysis: test t-test Student, $(+)$ statistically significant difference to control medium, $(-)$ statistically insignificant difference to control medium

Table II

Content of mycelium components produced by moulds in control medium and in medium with added mortar

\begin{tabular}{|c|c|c|c|c|c|c|}
\hline \multirow{2}{*}{\multicolumn{2}{|c|}{ Moulds mycelium component }} & \multicolumn{2}{|c|}{ Control medium Mo } & \multicolumn{2}{|c|}{ Mo+ -mortar } & \multirow{2}{*}{$\begin{array}{c}\text { Analysis of test } \\
\text { t-Student* }\end{array}$} \\
\hline & & $\mathrm{x}$ & $\mathrm{s}$ & $\mathrm{x}$ & $\mathrm{s}$ & \\
\hline \multirow[t]{3}{*}{ A. niger } & Glucan (mg/g dry mass mycelium) & 137.6 & 6.54 & 102.6 & 10.18 & + \\
\hline & Chitin (mg/g dry mass mycelium) & 209.2 & 11.77 & 123.4 & 9.91 & + \\
\hline & Ergosterol (mg/g dry mass mycelium) & 149 & 13.70 & 93.8 & 17.69 & + \\
\hline \multirow[t]{3}{*}{ A.flavus } & Glucan (mg/g dry mass mycelium) & 133 & 8.94 & 99.6 & 13.77 & + \\
\hline & Chitin (mg/g dry mass mycelium) & 103.8 & 5.40 & 89.8 & 8.58 & + \\
\hline & Ergosterol (mg/g dry mass mycelium) & 85.2 & 17.07 & 69.6 & 13.94 & - \\
\hline \multirow[t]{3}{*}{ P.chrysogenum } & Glucan (mg/g dry mass mycelium) & 194.4 & 10.64 & 121.8 & 10.21 & + \\
\hline & Chitin (mg/g dry mass mycelium) & 162.2 & 9.01 & 100.4 & 9.13 & + \\
\hline & Ergosterol (mg/g dry mass mycelium) & 151 & 11.77 & 96.2 & 12.32 & + \\
\hline
\end{tabular}

Legend: $\mathrm{x}=$ average value, $\mathrm{s}=$ standard deviation, ${ }^{*}$ statistical analysis: t-Student test, $(+)$ statistically significant difference to control medium, $(-)$ statistically insignificant difference to control medium 
Table III

Mould's extracellular enzymes produced on media with addition of building materials

\begin{tabular}{|l|l|l|l|l|l|}
\hline \multirow{2}{*}{ Moulds } & \multicolumn{6}{|c|}{ Extracellular enzymes detected after moulds culture on media with addition of building materials (API-Zym test)* } \\
\cline { 2 - 6 } & \multicolumn{1}{|c}{ Control medium Mo } & \multicolumn{1}{|c|}{ Mo + wallpaper } & Mo + carton-gypsum board & \multicolumn{1}{|c|}{ Mo + gypsum } & Mo + mortar \\
\hline A. niger & $2,3,4,5,6,7,8,9$, & $6(\downarrow), 10,11(\uparrow), 12(\uparrow)$, & $6(\uparrow), 11(\uparrow), 12, \mathbf{1 3}, \mathbf{1 4}$, & $3(\downarrow), 6(\downarrow), 11(\uparrow)$, & \\
& $10,11,12,16,17$ & $\mathbf{1 3}, \mathbf{1 4}, 17(\uparrow), \mathbf{1 8}$ & $17(\uparrow), \mathbf{1 8}$ & $12(\uparrow), \mathbf{1 3}, 17(\downarrow), 18$ & $11(\downarrow), 12$ \\
\hline A. flavus & $2,5,6,7,8,10,11,17$ & $\mathbf{3}, 7,11(\uparrow), \mathbf{1 2}, \mathbf{1 4}, \mathbf{1 8}$ & $\mathbf{3}, 6, \mathbf{1 2}$ & $11(\uparrow)$ & 11 \\
\hline P. chrysogenum & $5,8,10,11,17$ & $\mathbf{9}, 11, \mathbf{1 2}, \mathbf{1 4}, 17(\uparrow), \mathbf{1 8}$ & $\mathbf{6}, 11, \mathbf{1 2}, \mathbf{1 4}, 17, \mathbf{1 8}$ & $11(\uparrow), \mathbf{1 2}$ & $11, \mathbf{1 2}$ \\
\hline
\end{tabular}

* Enzymes (API-test): 1 control , 2 alkaline phosphatase, 3 esterase, 4 esterase lipase, 5 lipase, 6 leucine arylamidase, 7 valine arylamidase, 8 cystine arylamidase, 9 trypsin, $10 \lambda$-chymotrypsin, 11 acid phosphatase, 12 naphtol-AS-BI-phosphohydrolase, $13 \lambda$-galactosidase, $14 \beta$-galactosidase, $15 \beta$-glucuronidase, $16 \lambda$-glucosidase, $17 \beta$-glucosidase, $18 \mathrm{~N}$-acetyl- $\beta$-glucosaminidase, $19 \lambda$-mannosidase, $20 \lambda$-fucosidase; $(\uparrow)$ increase of enzyme level, $(\downarrow)$ decrease of enzyme level, bold - enzyme appears in the medium with building materials, but it is absent in control medium.

Table IV

Organic acids produced by moulds on media with addition of building materials

\begin{tabular}{|c|c|c|c|c|c|}
\hline \multirow{2}{*}{$\begin{array}{c}\text { Moulds/ } \\
\mathrm{pH} / \text { kind of } \\
\text { organic acid }\end{array}$} & \multicolumn{5}{|c|}{ Quantity of organic acids $(\mathrm{g} / 100 \mathrm{ml})$} \\
\hline & \begin{tabular}{|c|} 
Control medium Mo \\
initial pH $5.78 \pm 0.06$ \\
\end{tabular} & $\begin{array}{c}\text { Mo + wallpaper initial } \\
\text { pH } 5.79 \pm 0.18\end{array}$ & $\begin{array}{c}\text { Mo+ carton-gypsum board } \\
\text { initial pH } 6.43 \pm 0.27\end{array}$ & \begin{tabular}{|c|} 
Mo + gypsum initial \\
pH $6.92 \pm 0.25$ \\
\end{tabular} & $\begin{array}{c}\text { Mo }+ \text { mortar initial } \mathrm{pH} \\
10.24 \pm 0.29\end{array}$ \\
\hline \multicolumn{6}{|l|}{ A. niger } \\
\hline $\mathrm{pH}^{*}$ & $2.32 \pm 0.05$ & $4.74 \pm 0.15$ & $3.62 \pm 0.19$ & $4.56 \pm 0.18$ & $7.60 \pm 0.22$ \\
\hline Oxalic & 0.536 & 0.304 & nd & nd & 0.086 \\
\hline Malic & nd & 0.038 & 0.012 & 0.009 & 0.055 \\
\hline Succinic & 0.001 & nd & 0.003 & 0.012 & 0.006 \\
\hline \begin{tabular}{|l|} 
Fumaric \\
\end{tabular} & nd & nd & nd & 0.001 & 0.001 \\
\hline \multicolumn{6}{|l|}{ P. expansum } \\
\hline $\mathrm{pH}^{*}$ & $3.21 \pm 0.02$ & $4.71 \pm 0.23$ & $4.81 \pm 0.22$ & $5.40 \pm 0.21$ & $6.86 \pm 0.28$ \\
\hline Oxalic & 0.906 & 0.166 & 0.089 & 0.103 & 0.261 \\
\hline Malic & 0.048 & 0.019 & 0.054 & nd & 0.078 \\
\hline \begin{tabular}{|l|} 
Succinic \\
\end{tabular} & 0.042 & 0.004 & 0.055 & 0.035 & 0.068 \\
\hline Fumaric & 0.006 & nd & nd & nd & nd \\
\hline \multicolumn{6}{|c|}{ P. chrysogenum } \\
\hline $\mathrm{pH}^{*}$ & $3.82 \pm 0.03$ & $4.74 \pm 0.28$ & $4.79 \pm 0.15$ & $5.82 \pm 0.24$ & $7.09 \pm 0.15$ \\
\hline Oxalic & nd & nd & 0.241 & nd & 0.192 \\
\hline Malic & 0.006 & 0.023 & 0.022 & 0.007 & 0.543 \\
\hline \begin{tabular}{|l|} 
Succinic \\
\end{tabular} & 0.003 & nd & 0.025 & 0.003 & 0.051 \\
\hline Fumaric & 0.001 & nd & 0.003 & nd & nd \\
\hline \multicolumn{6}{|c|}{ Mean quantity of acids } \\
\hline Oxalic & 0.480 & 0.156 & 0.110 & 0.034 & 0.179 \\
\hline Malic & 0.018 & 0.026 & 0.029 & 0.005 & 0.225 \\
\hline Succinic & 0.015 & 0.001 & 0.028 & 0.016 & 0.042 \\
\hline Fumaric & 0.002 & nd & 0.001 & 0.001 & 0.001 \\
\hline \multicolumn{6}{|c|}{ Frequency of occurrence of acids* } \\
\hline Oxalic & $2 / 3$ & $2 / 3$ & $2 / 3$ & $1 / 3$ & $3 / 3$ \\
\hline Malic & $2 / 3$ & $3 / 3$ & $3 / 3$ & $2 / 3$ & $3 / 3$ \\
\hline Succinic & $3 / 3$ & $1 / 3$ & $3 / 3$ & $3 / 3$ & $3 / 3$ \\
\hline Fumaric & $2 / 3$ & $0 / 3$ & $1 / 3$ & $1 / 3$ & $1 / 3$ \\
\hline
\end{tabular}

nd - not detected in sample; * number of measurements $\mathrm{N}=3$

to the culture medium induced production of the enzymes: $\lambda$-galactosidase, $\beta$-galactosidase, $N$-acetyl- $\beta$ glucosaminidase, naphtol-AS-BI-phosphohydrolase. Similar results were obtained on a medium with carton-gypsum board (naphtol-AS-BI-phosphohydrolase, $\lambda$-galactosidase, $\beta$-galactosidase, $N$-acetyl- $\beta$-glucosa- minidase). In cultures on media with the addition of gypsum, significantly fewer enzymes were produced, and the level of some enzymes fell compared with the control medium without building materials. The least favourable to enzymatic activity was the medium with the addition of mortar. In mould cultures in medium 
containing mortar the production of only two enzymes was observed - acid phosphatase and naphtol-ASBI-phosphohydrolase.

Addition of building materials to media affected a change of the initial $\mathrm{pH}$ (Table IV). In medium with mortar the initial $\mathrm{pH}$ changed from $\mathrm{pH} 5.7$ to $\mathrm{pH} 10$, in media with other materials the initial $\mathrm{pH}$ ranged from 5.7 to 6.9. It was observed that the direction in the change of the $\mathrm{pH}$ of the medium depended on mould growth and was the same in media with building materials as in control medium, but the type of building material affected the formation of organic acids. The greatest decreased of $\mathrm{pH}$ was found in the medium containing mortar. In this medium moulds produced the greatest variety of organic acids (malic, succinic oxalic and fumaric acids) and in greater quantities than in the other media. In the wallpaper medium no intensive acidifying properties of the moulds were observed. In the medium with cartongypsum board only the production of malic and succinic acids was observed. The medium with gypsum induced the production of acids only in the case of A. niger strain.

\section{Discussion}

Mould growth on building materials depends on the origin of the materials (organic or inorganic). In the presented studies it was found that materials containing cellulose were the most favourable to the growth of Aspergillus and Penicillium moulds. The greatest increase in mycelium biomass was observed in medium with wallpaper. The moulds exploited the additional source of carbon from cellulose in wallpaper and carton-gypsum board. This is evidenced by the activation of the enzymes $\lambda$-galactosidase, $\beta$-galactosidase and $\mathrm{N}$-acetylo- $\beta$-glucosaminidase. There are reports in the literature of the enzymes cellulase and amylase produced by Chaetomium, Penicillium, Aspergillus, Stachybotrys, Cladosporium and Alternaria moulds, which are capable of causing biodegradation of various types of paper used for technical purposes (Rojas et al., 2008). Also the starch and casein-based glues used to stick wallpapers and cardboard to gypsum are decomposed by extracellular enzymes and may provide a source of carbon for moulds (Flannigan et al., 2001). It was found, however, that moulds in medium with the wallpaper produced few organic acids and only in small quantities. The mechanism responsible for the destruction of wallpaper and the cardboard on gypsum board was therefore enzymatic degradation.

The greatest changes in the growth and metabolic activity of moulds was found in media with the addition of building materials of inorganic origin, mainly with mortar. Moulds grew much more slowly in me- dium with mortar, attaining $60 \%$ less mycelium biomass, the quantity of the mycelium components-chitin, glucan, ergosterol - decreased $13-41 \%$. This is evidence of the presence in mortar of a factor impeding the growth of moulds, such as high $\mathrm{pH}$, presence of chemical compounds impeding the synthesis of cellular components $\left(\mathrm{CaSO}_{4}\right.$, oxides of $\mathrm{Ca}, \mathrm{Al}, \mathrm{Si}, \mathrm{Fe}, \mathrm{Mg}$, $\mathrm{K}, \mathrm{Na}, \mathrm{S}$, possibly biocides). The presence in the medium of inorganic compounds from mortar also significantly impeded the production of extracellular enzymes. The reason for this may have been the initial $\mathrm{pH}$ of the medium, particularly mortar $(\mathrm{pH}=10.2)$, which reduced the activity of most enzymes. However organic acids were found to be produced intensely on media with the addition of inorganic building materials. Taking advantage of the presence in the medium of the sugars essential for initiation of growth, which simulated organic contaminations, the moulds produced - on the building materials - succinic, malic and oxalic acids and small quantity of fumaric acid. It was observed that succinic and malic acids were released into the medium containing mortar in significantly greater quantities than in the control medium. The high $\mathrm{pH}$ of mortar probably directed the mould's metabolism towards the production of these organic acids. The phenomenon of increased production of acid induced by a rise in the $\mathrm{pH}$ of the medium is observed in the production of citric acid by A. niger (Magnuson and Lasure, 2004). The organic acids produced by Penicillium, Aspergillus and Trichoderma moulds are strong corrosive agents (de la Torre et al., 1991; de La Torre and Gomez-Alarcon, 1994). Organic acids may cause dissolution of the mineral components in building materials, in particular of cations of $\mathrm{Mg}, \mathrm{Ca}$, $\mathrm{Al}, \mathrm{Mn}, \mathrm{Fe}, \mathrm{Si}, \mathrm{K}$ (Warscheid and Braams, 2000). This process has been confirmed on sandstone and granite (de La Torre and Gomez-Alarcon, 1994; Sand, 1974). The ability of moulds to release calcium from concrete has also been described, leading to losses of material mass (Gu et al., 1998). With cations, organic acids like citric, gluconic and malic form salts that are water-soluble, while oxalic and succinic acids form insoluble salts such as calcium oxalate and ferric oxalate (Gomez-Alarcon and de La Torre, 1994). Our studies showed increased production of malic and succinic acids on mortar and gypsum board, and hence it was confirmed that both water-soluble and insoluble salts can be formed.

The presented differences in the production of enzymes and organic acids by moulds when growing on media with the addition of building materials of organic and inorganic origin indicate two mechanisms of activity of moulds in the biodeterioration of building materials. Having an available carbon source and optimum $\mathrm{pH}$, on organic materials moulds produce principally mycelium and extracellular enzymes, while 
on inorganic materials, where mycelium growth is impeded, they increase production of organic acids. Organic acids produced in oligotrophic conditions by moulds may be the reason for microbial corrosion on inorganic building materials.

\section{Acknowledgments}

Sincere thanks to dr Agata Czyżowska, from the Institute Technology Fermentation and Microbiology, Technical University of Łódź, for her help with HPLC analysis.

\section{Literature}

de La Torre M.A. and G. Gomez-Alarcon. 1994. Manganese and iron oxidation by fungi isolated from building stone. Microbiol. Ecol. 27: 177-188.

de La Torre M.A., G. Gomez-Alarcon, P. Melgarejo and C. Saiz-Jimenez. 1991. Fungi in weathered sandstone from Salamanca cathedral, Spain. Sci. Total Environ. 107: 159-168.

Flannigan B., R.A. Samson and J.D. Miller. 2001. Microorganisms in home and indoor environments, Harvard Academic, UK.

Gomez-Alarcon G. and M.A. de la Torre. 1994. The effect of filamentous fungi on stone monuments: the Spanish experience. In: Building Mycology. Management of decay and health in buildings, Singh J. (ed), Chapman and Hall, UK, p. 295-309.

Gomez-Alarcon G., M.L. Munoz and M. Flores. 1994. Excretion of organic acids by fungal strains isolated from decayed sandstone. Int. Biodeter. Biodeg. 34: 169-180.

Gu J.D., T.E. Ford, N.S. Berke and R. Mitchell. 1998. Biodeterioration of concrete by the fungus Fusarium. Int. Biodeter. Biodeg. 41: 101-109.

Gutarowska B. and Z. Żakowska. 2002. Elaboration and application of mathematical model for estimation of mould contamination of some building materials based on ergosterol content determination. Int. Biodeter. Biodeg. 49: 299-305.

Gutarowska B., M. Wiszniewska, J. Walusiak, M. Piotrowska, C. Palczyński and Z. Żakowska. 2005. Exposure to moulds in flats and the prevalence of allergy diseases - preliminary study. Polish J. Microbiol. 54: 13-20.

Kisser M., P. Kubicek and M. Rhor. 1980. Influence of manganese on morphology and cell wall composition of $A$. niger during citric acid fermentation. Arch. Microbiol. 128: 26-33.
Korpi A., A.L. Pasanen, P. Pasanen and P. Kalliokoski. 1997. Microbial growth and metabolism in house dust. Int. Biodeter. Biodeg. 40: 19-27.

Magnuson J.K. and L.L. Lasure. 2004. Organic acid production by filamentous fungi. In: Advances in fungal biotechnology for industry, agriculture and medicine, Tkacz J.S., Lange L. (eds.), Kluwer Academic/Plenum Publisher, p.307-339.

Nielsen K.F., G. Holm, L.P. Uttrup and P.A. Nielsen. 2004 Mould growth on building materials under low water activities. Influence of humidity and temperature on fungal growth and secondary metabolism. Int. Biodeter. Biodeg. 54: 325-336.

Nielsen K.F., U. Thrane, L.T.O. Arsen, P.A. Nielsen and S. Gravesen. 1998. Production of mycotoxins on artificially inoculated building materials. Int. Biodeter. Biodeg. 42: 8-16.

Palmer R.J., J. Siebert and P. Hirsch. 1991. Biomass and organic acids in sandstone of a weathering building: production by bacterial and fungal isolates. Microb. Ecol. 21: 253-266.

Pasanen P., A. Korpi, P. Kalliokoski and A.L. Pasanen. 1997. Growth and volatile metabolite production of Aspergillus versicolor in house dust. Environ. Int. 23: 425-432.

Petersen K., J. Kuroczkin, A.B. Strzelczyk and W.E. Krumbein. 1987. Disttribution and effects of fungi on and in sandstone, In: Biodeterioration, Houghton D.R., Smith R.N., Heggins H.O.W., (eds.), $7^{\text {th }}$ ed. Elsevier, London, UK, p. 123-128. Rojas J.A., C.Cruz, J.F. Mikan, L.S. Villalba, M.C. Cepero de Garcia and S. Restrepo. Isoenzyme characterization of proteases and amylases and partial purification of proteases from filamentous fungi causing biodeterioration of industrial paper. Int. Biodeter. Biodeg. 63: 169-175.

Rokem J., D. Klein, H. Toder and E. Zomer. 1986. Degradation of fungal cell walls taking into consideration the polysaccharide composition. Enzyme Microb. Technol. 8: 588-592.

Samson R.A., E.S. Hoekstra, J.C. Frisvad and O. Filtenborg. 2000. Introduction to food and air borne fungi, $6^{\text {th }}$ ed. Centraalbureau voor schimmelcultures, Utrecht.

Sanchez-Silva M. and D.V. Rosowsky. 2008. Biodeterioration of construction materials: state of the art and future challenges. J. Mat. Civ. Engineer. 20: 352-365.

Sand W. 1997. Microbial mechanisms of deterioration of inorganic substrates - a general overviev. Int. Biodeter. Biodeg. 40: 183-190. Van Lancker F., A. Adams, B. Delmulle, S. De Saeger, A. Moretti, C. Van Peteghem and N. De Kimpe. 2008. Use of headspace SPME-GC-MS for the analysis of the volatiles produced by indoor molds grown on different substrates. J. Environ. Monitor. 10: 1127-1133.

Warscheid Th. and J. Braams. 2000. Biodeterioration of stone; a review. Int. Biodeter. Biodeg. 46: 343-368. 